\title{
Nipew New Disease Reports \\ First report of Horsegram yellow mosaic virus infecting Phaseolus vulgaris in Sri Lanka
}

W.A. Monger ${ }^{1 *}$, V. Harju ${ }^{1}$, T. Nixon ${ }^{1}$, S. Bennett ${ }^{1}$, R. Reeder ${ }^{2}$, P. Kelly ${ }^{2}$ and H.M. Ariyarathne ${ }^{3}$

${ }^{1}$ Food and Environment Research Agency, Sand Hutton, York, YO41 1LZ, UK; ${ }^{2}$ Global Plant Clinic, CABI, Bakeham Lane, Egham, Surrey, TW20 9TY, UK; ${ }^{3}$ Horticultural Crop Research and Development Institute, Department of Agriculture; 25 Old Galaha Road, Peradeniya, Sri Lanka

*E-mail: wendy.monger@fera.gsi.gov.uk

Received: 12 Feb 2010. Published: 09 May 2010.

Bean (Phaseolus vulgaris) is one of the most important vegetables in Sri Lanka. In 1999, a new bean disease was reported from the town of Balangoda, Sri Lanka. Symptoms included a bright yellow mosaic pattern on the leaves, rugosity, reduced leaf size and stunting of the entire plant. Depending upon the time of infection, plants either produced fewerflowers and pods or none at all. Since its discovery the disease hasspread to most bean growing areas of the island. In 2009, six samplesshowing symptoms were collected from different districts of Sri Lankafor viral analysis. All were tested by ELISA for Tomato spotted wilt virus, Impatiens necrotic spot virus, Cucumber mosaic virus (CMV), Southern bean mosaic virus, and with broad-spectrum antisera for potyviruses and begomoviruses. One sample tested positive for potyviruses and another for CMV; all tested positive for begomoviruses.

DNA was extracted from three of the plants and subjected to rollingcircle amplification using Phi 29 (G E Healthcare). Amplicons werecut with Rsa I, cloned and sequenced using the Topo blunt vector II (Invitrogen). All samples gave portions of DNA-A and B of a bipartite begomovirus; a Blast search of the GenBank database revealed high sequence identity to Horsegram yellow mosaicvirus (HgYMV). The complete viral genome was obtained from one sample using specific PCR primers. Component A contained 2735 nucleotides and component B contained 2669 nucleotides (GenBank Accession Nos. GU323321/2). Component A shared between 95.1 and $96.6 \%$, and component B between 93.5 and $96.3 \%$ sequence identity with the four available genomes in GenBank (alignments using Clustal V and MegAlign DNAStar). HgYMV hasbeen identified in India where it was found to infect variouslegumes: bambara groundnut, French bean, groundnut, lima bean, mungbean, pigeon pea, soybean and horse

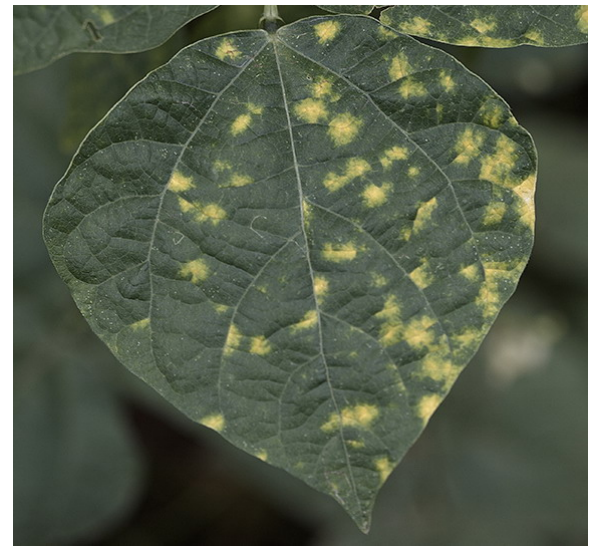

Figure 1

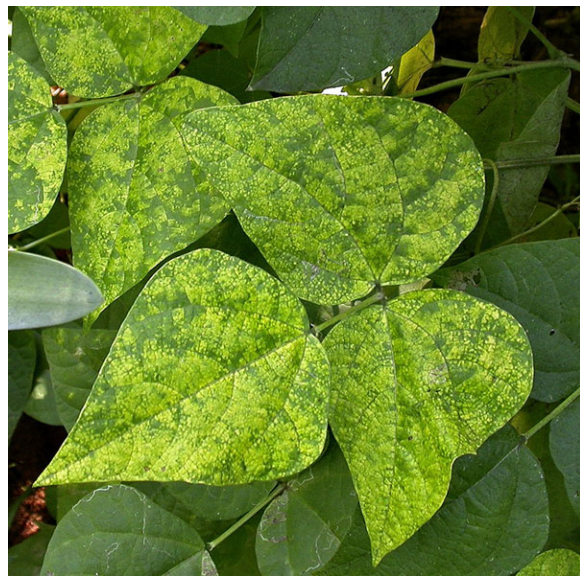

Figure 2 gram (Muniyappa etal., 2008). All cultivated bean varieties are susceptible and the diseaseis regarded as the most serious threat to bean production in SriLanka. Using the current taxonomic nomenclature (Fauquet etal., 2008) we propose the name Horsegramyellow mosaic virus-[Sri Lanka:2009] HgYMV-[LK:09] for this variant of the virus. This is the first report of the virus in Sri Lanka.

\section{Acknowledgements}

Our thanks to the staff of HORDI for carrying out the initial research into the disease and for facilitating the GPC visit to Sri Lanka to collect samples

\section{References}

Fauquet CM, Briddon RW, Brown JK, Moriones E, Stanley J, Zerbini M, Zhou X, 2008. Geminivirus strain demarcation and nomenclature. Archives of Virology153, 783-821. [doi:10.1007/s00705-008-0037-6]

Muniyappa V, Rajeshwari R, Bharathan N, Reddy DNR, Nolt BL, 2008. Isolation and characterization of a geminivirus causing yellow mosaic disease of horsegram (Macrotyloma uniflorum [Lam.] Verdc.) in India. Journal of Phytopathology 119, 81-87. [doi:10.1111/j.1439-0434.1987.tb04386.x]

To cite this report: Monger WA, Harju V, Nixon T, Bennett S, Reeder R, Kelly P, Ariyarathne HM, 2010. First report of Horsegram yellow mosaic virus infecting Phaseolus vulgaris in Sri Lanka. New Disease Reports 21, 16. [doi:10.5197/j.2044-0588.2010.021.016] 